\title{
Role Playing in Storytelling Classes and Its Impact on Iranian Young EFL Learners' Narrative Writing
}

\author{
Mojgan Rashtchi \\ Islamic Azad University
}

Correspondence concerning this article should be addressed to Mojgan Rashtchi, TEFL Department, Faculty of Foreign Languages, Islamic Azad University, North Tehran Branch, 1651153311. E-mail: mojgan.rashtchi@gmail.com

\author{
Mosayeb Moradzadeh \\ Islamic Azad University
}
Correspondence concerning this article should be addressed to Mosayeb Moradzadeh, TEFL Department, Faculty of Foreign Languages, Islamic Azad University, North Tehran Branch, 1651153311. E-mail: moradzadeh333@yahoo.com

\begin{abstract}
The present study aimed to investigate the effect of role playing in storytelling classes on Iranian young EFL learners' narrative writing. Forty-seven pre-intermediate young EFL learners who were within the age range of 9 and 16 participated in this study. They were members of four intact classes, which consisted of two classes of boys and two classes of girls. One class of boys and one class of girls were randomly assigned to the experimental groups and the other two to control groups. The researchers used the role-playing technique for storytelling classes in the experimental groups and only reading stories aloud for storytelling classes in the control groups. After the treatment, the Multivariate Analysis of Variance (MANOVA) was run to compare the four groups' improvement on narrative writing. The results signified that the use of role playing in the storytelling classes had a significant impact on the narrative writing of Iranian young EFL learners as compared to the reading stories aloud technique. Furthermore, the findings showed that using role playing in storytelling classes enhanced learners' understanding of the narrative writing style and patterns of the target language.
\end{abstract}

Keywords: narrative writing, reading a story aloud, role play, storytelling, young EFL learners

The act of writing as a multifaceted process requires the coordination of numerous low and high-level skills (Smith, 2011) no matter which type of writing; that is, expository, descriptive, persuasive, or narrative is employed. When authors write in a narrative style, they do not merely try to impart information, but they attempt to construct and communicate a story, complete with characters, conflict, and settings ${ }^{1}$. The present study aimed to examine whether the use of the role-playing technique in storytelling classes affects Iranian young EFL learners' narrative writing. In line with Huang (2008), we believe that the technique can change the atmosphere of EFL classes and help students learn to use the language more realistically and practically.

Writing instruction usually occurs after children

1 Jeffrey, R. (2016). About writing: A guide. Austin, TX: Open Oregon Educational Resources. enter school, whereas children's oral language skills begin to develop long before children receive their first writing lesson. Therefore, we believe that storytelling can help teachers manipulate oral skills for the improvement of the writing skill, which is usually difficult for EFL learners. One source of difficulty emerges from the fact that writing cannot be practiced through real-life conversations or situations (Raftari, Ismail, \& Eng, 2016).Another severe problem in teaching writing, as pointed out by Cook (2000), is that some learners refuse to undertake any writing tasks. We believe that this problem can be solved by resorting to the role-playing technique because it can encourage learners to participate in writing tasks eagerly.

For improving young learners' writing skill, we believe that strategies should be used that engage students in the process of instruction and we should 
also teach writing implicitly. By employing role playing, as Smith (2011) put forward, we manipulate oral language to become a natural foundation for the writing skill. However, the research literature exploring the relationship between oral language and text-level writing is limited, and few studies have examined the impact of oral language on composition writing. The results of this study suggest teachers consider the technique for teaching narrative writing.

\section{Literature Review}

Narration has been the basic model of recounting information throughout history, and it is through narration that human ideas and emotions are shared (Fraser, 2015). Narrative writing is something like writing a story or report of events, personal experiences, or any similar events, whether they are real or fictional ${ }^{2}$. As Harmer (2004) maintained, limitations of certain genres influence the process of writing, and writing is a process with different stages that needs planning and training. Also, Boardman (2002) pointed out that writing is a process of thinking and organizing, rethinking, and reorganizing. As a result, planning and models are necessary for writing a good story.

Narrative writing is a difficult skill for learners in EFL classrooms because they do not know where to begin and how to organize the materials, and thus put things in inappropriate places, which makes their products meaningless ${ }^{3}$. Thus, Birjandi and Malmir (2009) signified that the task-based approach was more effective for teaching narrative writing compared to the traditional approach. They asserted that one of the reasons for the outperformance of the task-based classes in comparison to the traditional classes is the collaborative and interactive nature of the task-based approach where language use and language learning take place simultaneously. Moreover, Abbasi (2017) investigated the effect of using task-based activities on the narrative writing performance and showed that such activities enhanced the narrative writing of Iranian EFL learners. Also, Adam (2015) studied the effect of short stories on the narrative writing of EFL learners in Al-Baha University and concluded that using short stories in EFL classrooms positively contributes to the progress of students' narrative writing.

As stated above, this study investigated the impact of the role-playing technique on improving learners' narrative writing. In this regard, we can refer to constructivism as one of the theories that shaped the

\footnotetext{
2 Baldick, C. (2008). Oxford dictionary of literary terms. Oxford, UK: Oxford University Press.

3 Kies, D. (1995). Coherence in writing: The hyper textbooks. Retrieved fromhttp://papyr.com/hypertextbooks/comp1/coherent.htm
}

theoretical basis of the study. Constructivists believe learning occurs through social intervention in which learners construct knowledge from their environment (Ormrod, 2012). One outcome of constructivism is the communicative approach to language instruction (Canale, 1983), and its central tenet is the need to practice language functions in different situations to achieve communicative competence in written and oral discourse. Role playing, as one of the techniques that is employed in the communicative approach to teaching a second language, involves giving a real or fictional role to one or more members of a group and assigning an objective or purpose that the participants must accomplish (Brown, 2001). It provides different situations for learners to communicate with each other and practice the language. The interactive feature of role playing makes the target language comprehensible with support systems like body gestures, and positive and negative feedback alerts. Like other types of play (Rogers \& Evans, 2008), role playing can foster the healthy growth and development of young children and can support learning.

It is worth mentioning that there are two types of learning; that is, active and passive. Active learning engages learners directly in the learning process in some way and at differing degrees of interaction, whereas passive learning occurs indirectly and without interaction. Active learning is preferred because it triggers cognitive functioning and is related to the theory of situated cognition where one's actions and understandings are governed by environmental clues in physical and social settings (Rogers, 2017). The role-playing technique is in the category of active learning as it involves the participation of learners in tasks or draws their attention to the flow of events in the classroom. According to Csikszentmihalyi (1990), within the framework of flow theory, eight components are needed to produce the optimal conditions for learning; they include: manageable tasks, deep concentration, clear goals, immediate feedback, effortless involvement, learner autonomy, a metamorphosis of self, and suspension of time. Most of these seem to be present in role playing.

The critical feature of role playing is that learners can become someone they want for a short time, for example, a captain, an old man, a prisoner, or a wealthy man, which may reduce the fear of speaking because it is the characters that make mistakes, not them (Golebiowska, 1987). Role-play strategies have shown their effectiveness in teaching English to learners, as role play can increase students' enthusiasm, selfconfidence, and empathy, and encourage critical thinking (Alabsi, 2016). A review of the literature shows that several researchers have indicated the benefits of employing the role-playing technique. For example, Tompkins (1998) used the role-playing 
technique for teaching conversation and found out that it is an extremely valuable method for L2 learning; it encourages thinking and generates creativity. Tompkins believed that role playing could help students practice the new language in a relatively nonthreatening setting. Also, Sadeghi and Sharifi (2013) who studied the effect of role playing, games, narrative writing, and speaking tasks on the vocabulary gain of elementary Iranian EFL learners showed that role play leads to the highest vocabulary gain compared to other strategies. Besides, Toumpaniari, Loyens, Mavilidi, and Paas (2015) indicated that learning by embodying words through physical activities boosts children's learning. Additionally, Altun's (2015) case study on the implementation of role-playing activities discovered that such activities enhanced the participants' selfconfidence, motivation, and the foreign language speaking skills.

On the other hand, the rationale behind the use of role playing to teach narrative writing via short stories can relate to implicit learning. Implicit learning plays a role in language acquisition and often involves learning a set of rules of some paradigm. As originally conceptualized by Reber (1967), studies of implicit learning focus on the acquisition of the underlying structure of a context, such as the acquisition of rules of an artificial grammar that underlie strings of letters, without intention or awareness. Implicit learning has been broadly defined as learning without awareness or the ability to derive information about the world in an unconscious, non-reflective way (Winter \& Reber, 1994). Ellis (1994) attributed specific characteristics to implicit learning. As Ellis argued, implicit learning is accessible, abstract and structured, and it can be analyzed and transferred into explicit knowledge. According to Ellis, implicit learning happens through the use of language naturally. Different scholars (e.g., Evans, Saffran, \& Robe-Torres, 2009; Leung \& Williams, 2011) have conducted studies to demonstrate the effectiveness of implicit learning is SLA. The present study investigated whether the participants implicitly learned concepts like style, pattern, and organization from role-playing techniques and used them in their narrative writing.

It is difficult to imagine that one could comprehend written texts or construct written sentences without having some knowledge of the various aspects of oral language such as vocabulary and grammar; thus, children who are not strong enough in oral language skills may be limited in their ability to express themselves adequately in writing (Smith 2011). Teitelbaum and Gillis (2004) insisted that drama instruction is an arts-based teaching method and it is positively correlated with writing quality. Moore and Caldwell $(1990,1993)$ examined the value of drama work as a rehearsal for writing and looked at how drama promotes narrative writing with primary school children. One of the values of developing drama with young learners is that it engages them in thinking, doing, and imagining so that when they begin to compose texts, they weave these threads together in unexpected and exciting ways (Crumpler, 2005).

Thus, the following research question and null hypothesis were formulated to serve the purpose of the study, which was investigating the effect of role playing in storytelling classes on the narrative writing of young EFL learners. Does the employment of role plays in storytelling classes affect the narrative writing of Iranian young EFL learners? According to the authors' hypothesis, there is no statistically significant difference between the narrative writing of Iranian young EFL learners who engage in role playing of short stories and those who read them aloud.

\section{Materials and Methods}

\section{Participants}

The participants in this study included 47 preintermediate young EFL learners within the age range of 9 to 16 in an English language institute in Tehran. They were members of four intact classes, which consisted of two classes of boys and two classes of girls. Participants were selected based on convenience sampling. One class of boys consisted of 12 learners, and one class of girls consisted of 13 learners randomly assigned to the experimental groups. The other two classes assigned to the control groups consisted of 13 boys and 9 girls. The participants were screened via the placement test administered by the institute, and all participants were in pre-intermediate level (studying the final part of American English File 1); thus, no general proficiency test, as a homogenizing test, was administered.

\section{Instruments}

The Georgia Department of Education (GADOE) eighth-grade writing rubric (Appendix A) was the instrument that the researchers used for assessment of the narrative writing of the participants in the Pre-test and Post-tests. The GADOE rubric was developed in 2007 and is a holistic tool to produce an analytic score providing information about students' writing performance including areas of strength and challenge $\mathrm{e}^{4}$. The GADOE narrative writing rubric is

\footnotetext{
4 Georgia Department of Education (GADOE). (2014). English Language Arts (ELA) writing rubrics (pp. 63-65). Georgia Milestones Grade 8 EOGStudy/Resource Guide for Students and Parents. Retrieved from https://www.clayton.k12.ga.us/UserFiles/
} 
designed to analyze the domains of writing and reflects the students' overall performance on a composition, using predetermined scoring criteria on a four-point scale in each domain; ideas, organization, style, and conventions ${ }^{5}$. Rubrics assist the raters by providing articulated expectations and scales for measuring the achievement and well-constructed rubrics provide a common language that clarifies expectations, benefiting both teachers and students (Miller, 2010).

\section{Materials}

The present study employed a collection of stories that the researcher had gathered from different websites (Appendix B). The selection of the stories was based on the applicability of assigning the characters of the story to students that then employed the roleplaying technique in the experimental groups. The English teacher in this research used this collection of stories for both participants in the experimental and control groups.

\section{Design and Variables}

The present study was a quasi-experimental study because the participants were not selected randomly. The design selected for the study was the nonequivalent control group Pre-test/Post-test design. This is one of the designs used for quasi-experimental studies in which two independent groups are selected non-randomly. The study intended to investigate the effect of role playing in storytelling classes on Iranian young EFL learners' narrative writing. Role playing was the independent variable and narrative writing was the dependent variable in this study.

\section{Procedure}

There were two experimental groups and two control groups in this study. The experimental groups consisted of one group of boys and one group of girls. The control groups also comprised one group of boys and one group of girls. This study was implemented during one term in an English language institute in Tehran. Each term in the institute consisted of 16 sessions, and each session took 90 minutes The whole term took eight weeks, and there were two sessions each week. The researchers used the role-playing technique for storytelling classes in the experimental groups and only reading stories aloud for storytelling classes in the control groups.

\footnotetext{
Servers/Server 54431/File/Resources/GMASGuides/Grade\%208/ Grade\%208\%20Language\%20Arts\%20-\%20Sample\%20Rubrics. pdf

5 Ibid.
}

\section{Experimental groups}

The experimental groups consisted of one group of boys and one group of girls. Participants in these groups were exposed to the treatment that involved role playing while reciting the stories. In each session, the teacher handed out the stories and gave a general view of the stories and the characters. Then the teacher assigned different characters to volunteers based on the story that had to be practiced the following session and explained about the realia that they could use and how they had to play their roles. Participants could use photos, masks, and other aids for their performance. Those who volunteered memorized the dialogues and practiced their roles at home. Similar to the control groups, the teacher asked the participants to read the stories at home in advance. The following session, the teacher asked volunteers to play the roles in the story in front of their classmates. Players were permitted to write their dialogues on cards and, if they forget what to say, they could use the cards.

For the initial sessions, most of the participants did not tend to volunteer to play the roles in the stories in front of their classmates; therefore, the teacher selected the stories that needed only two or three main players for the initial sessions. After three sessions, most of the participants eagerly volunteered to play the roles in the stories. There were some differences between the performances of the boys and girls. The players in the boys' group were often looking for opportunities to say something outside of the story to make their classmates laugh or to perform something outside of the predetermined roles to have fun. In contrast, the girl players frequently stuck to their dialogue and roles to do their best. Another difference was related to reciting the dialogues of the stories. Most of the players in the boys' group did not recite their dialogues from memory and looked at the role cards.

In comparison, most of the girl players recited their dialogues from memory and seldom needed to look at the role cards. After the role play, the teacher asked the participants to discuss the story and make their comments. Participants were exposed to the treatment for 13 sessions over seven weeks.

\section{Control groups}

The control groups consisted of one group of boys and one group of girls. Participants in the control groups read the stories aloud in the class. They had to read the stories in advance at home. In each session, the teacher first asked the participants to define the new vocabulary items and then gave more explanations if it was necessary to clarify the meaning of the new vocabulary items. Some problems were noticed in the 
control groups by the teacher. Most of the participants in the control group classes did not read the stories in advance at home or find the meaning of the new vocabulary items. Participants in the control groups got bored because they had to read the stories several times in the classroom. Reading the stories aloud in the control groups was less time-consuming than role playing in the experimental classes; thus, the participants in the control groups had extra time to practice. After reading a story, the teacher asked the participants to discuss the story and comment on its content.

Pre-test. The teacher administered the Pre-test during the first session. She gave a topic to all of the participants in the experimental and control groups, and they wrote a story about a memory that they will never forget as the Pre-test. At the beginning of the Pre-test, the teacher explained that they could write either real or fictional stories or the combination of the two.

Post-tests. In order to compare the efficiency of the teaching method in each of the groups, the teacher administered the Post-tests immediately after the completion of the treatment with the same topic from the Pre-test and with a different topic during the following session. In the first session after the treatment, the teacher asked students to write a story about a memory that they will never forget, and during the following session, the teacher asked them to write a story about a scary dream they had. The teacher chose a time limitation of one hour for writing the stories, which could be real or fictional or a combination of the two.

\section{Results}

Table 1

Descriptive Statistics of the Groups

\begin{tabular}{lllllll}
\hline & Group & N & Mean & $\begin{array}{c}\text { Std. } \\
\text { Deviation }\end{array}$ & $\begin{array}{c}\text { Std. Error } \\
\text { Mean }\end{array}$ \\
\hline \multirow{2}{*}{ Pre-test } & Experimental & 25 & 10.8400 & 1.95107 & .39021 \\
\cline { 2 - 7 } & Control & 22 & 11.2727 & 1.85631 & .39577 & \\
\hline
\end{tabular}

Table 2

Independent Samples Test

\begin{tabular}{|c|c|c|c|c|c|c|c|c|}
\hline \multirow{2}{*}{$\mathrm{F}$} & & \multicolumn{2}{|c|}{$\begin{array}{l}\text { Levene's Test for } \\
\text { Equality of Variances }\end{array}$} & \multicolumn{2}{|c|}{$\begin{array}{l}\text { t-test for Equality } \\
\text { of Means }\end{array}$} & \multicolumn{3}{|c|}{ t-test for Equality of Means } \\
\hline & & Sig. & $\mathrm{t}$ & $\mathrm{df}$ & $\begin{array}{c}\text { Sig. } \\
\text { (2-tailed) }\end{array}$ & $\begin{array}{c}\text { Mean } \\
\text { Difference }\end{array}$ & $\begin{array}{l}\text { Std. Error } \\
\text { Difference }\end{array}$ & \\
\hline Pre-test & Equal variances assumed & .614 & .437 & -.776 & 45 & .442 & -.43273 & .55759 \\
\hline
\end{tabular}

Different statistical analyses were conducted to answer the research question of this study that stated: 'Does the employment of role plays in storytelling classes affect the narrative writing of Iranian young EFL learners?' An independent-samples t-test was conducted to compare the narrative writing of the experimental and control groups on the Pre-test before the advancement of the study. The results in Tables 1 and 2 illustrate that there was no statistically significant difference between the scores of the experimental $(\mathrm{M}=10.84, \mathrm{SD}=1.95)$ and control groups $(\mathrm{M}=11.27, \mathrm{SD}=1.86)$ on the Pre-test, $\mathrm{t}(45)=2.89, \mathrm{p}=0.44$.

A Multivariate Analysis of Variance (MANOVA) was conducted to examine the mean differences between the experimental and control groups on the two Posttests.

It is apparent from Table 3 that the means of the experimental groups on the first and second Posttests $(M=13.40 ; M=13.00)$ are higher than the control groups ( $\mathrm{M}=11.91 ; \mathrm{M}=11.32)$.

Table 4 reports the normality of the distribution of the scores. To ensure that the participants were normally distributed in each of the experimental and control groups, and due to the number of the participants totaling fewer than 100, a Shapiro-Wilk test was run. The results indicated no significant differences between the two groups; thus, it could be concluded that the scores in both groups were normally distributed. According to Table 4, the experimental groups for the first Post-test ( $\mathrm{p}=.105$ ) and second Posttest $(p=.058)$; the control groups for the first Posttest $(\mathrm{p}=.115)$ and second Post-test $(\mathrm{p}=.066)$ showed a normal distribution of scores.

In the next step, it was necessary to ensure that, for each of the levels of the between-subject variables, the pattern of intercorrelation among the levels of withinsubjects variables was the same. Box's M statistic tested the null hypothesis that the observed covariance 
Table 3

Descriptive Statistics

\begin{tabular}{|c|c|c|c|c|c|}
\hline & Gen & Group & Mean & Std. Deviation & $\bar{N}$ \\
\hline \multirow{6}{*}{ Pre-test } & \multirow{2}{*}{ Male } & Experimental & 11.0000 & 2.13201 & 12 \\
\hline & & Control & 11.9231 & 1.38212 & 13 \\
\hline & \multirow{2}{*}{ Female } & Experimental & 10.6923 & 1.84321 & 13 \\
\hline & & Control & 10.3333 & 2.12132 & 9 \\
\hline & \multirow{2}{*}{ Total } & Experimental & 10.8400 & 1.95107 & 25 \\
\hline & & Control & 11.2727 & 1.85631 & 22 \\
\hline \multirow{6}{*}{ First Post-test } & \multirow{2}{*}{ Male } & Experimental & 13.0833 & 2.10878 & 12 \\
\hline & & Control & 12.4615 & 1.33012 & 13 \\
\hline & \multirow{2}{*}{ Female } & Experimental & 13.6923 & 1.65250 & 13 \\
\hline & & Control & 11.1111 & 1.96497 & 9 \\
\hline & \multirow{2}{*}{ Total } & Experimental & 13.4000 & 1.87083 & 25 \\
\hline & & Control & 11.9091 & 1.71573 & 22 \\
\hline \multirow{6}{*}{ Second Post-test } & \multirow{2}{*}{ Male } & Experimental & 13.0000 & 1.90693 & 12 \\
\hline & & Control & 12.0769 & 1.44115 & 13 \\
\hline & \multirow{2}{*}{ Female } & Experimental & 13.0000 & 1.73205 & 13 \\
\hline & & Control & 10.2222 & 1.92209 & 9 \\
\hline & \multirow{2}{*}{ Total } & Experimental & 13.0000 & 1.77951 & 25 \\
\hline & & Control & 11.3182 & 1.86155 & 22 \\
\hline
\end{tabular}

Table 4

Shapiro-Wilk's Tests of Normality

\begin{tabular}{lcccc}
\hline \multirow{2}{*}{ Group } & \multicolumn{2}{c}{ First Post-test } & \multicolumn{2}{c}{ Second Post-test } \\
\cline { 2 - 5 } & Statistic & Sig. & Statistic & Sig. \\
\hline Experimental & 0.922 & 0.105 & 0.913 & 0.058 \\
Control & 0.929 & 0.115 & 0.917 & 0.066 \\
\hline
\end{tabular}

matrices of the dependent variables were equal across groups. Table 5 indicates that the assumption was met $(\mathrm{F}=1.349, p=.146)$.

Table 5

Box's Test of Equality of Covariance Matrices

\begin{tabular}{lc}
\hline Box's M & 28.022 \\
F & 1.349 \\
df1 & 18 \\
df2 & 5193.052 \\
Sig. & .146 \\
\hline
\end{tabular}

Table 6 indicates that there was a change in the narrative writing ability of the participants in the Post-tests (Wilks' Lambda value $=0.194, \mathrm{~F}=56.652$, $p<$ .001 ). The eta squared value was 0.806 , showing a large effect size (utilizing the commonly used guidelines by Cohen, 1988, namely, $0.01=$ small, $0.06=$ moderate, $0.14=$ large).

Table 7 shows the results of the Levene's test for the homogeneity of variances $(p>.05)$ which legitimizes conducting the test of between-subjects effects.

As Table 8 indicates, there was a significant difference between the narrative writing of the participants in the experimental and control groups on both Post-tests $(p<.05)$. The partial eta squared values for the first Post-test $(\eta 2=0.180)$, and second Post-test $(\eta 2=0.232)$ show that using role playing in storytelling classes by itself accounted for $18 \%$ of the overall variance on the first Post-test and almost 23\% on the second Post-test.

a. Squared $=.221$ (Adjusted R Squared $=.167)$

b. Squared $=.283$ (Adjusted R Squared $=.233$ )

As Table 9 shows, the experimental groups outperformed the control groups on both Post-tests (MD1=1.601; MD2=1.85; $p<.05)$.

\section{Discussion}

The results obtained from the statistical analysis showed that the use of role playing in storytelling classes had a more significant effect on the narrative writing of Iranian young EFL learners than the reading a story aloud technique. The finding can be related to constructivism, which is the dominant learning 
Table 6

Multivariate Tests

\begin{tabular}{|c|c|c|c|c|c|c|c|}
\hline & Effect & Value & $\mathrm{F}$ & $\mathrm{df}$ & Error df & Sig. & Partial Eta Squared \\
\hline \multirow{4}{*}{ 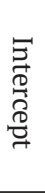 } & Pillai's Trace & .985 & 912.086 & 3.000 & 41.000 & .000 & .985 \\
\hline & Wilks' Lambda & .015 & 912.086 & 3.000 & 41.000 & .000 & .985 \\
\hline & Hotelling's Trace & 66.738 & 912.086 & 3.000 & 41.000 & .000 & .985 \\
\hline & Roy's Largest Root & 66.738 & 912.086 & 3.000 & 41.000 & .000 & .985 \\
\hline \multirow{4}{*}{ 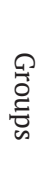 } & Pillai's Trace & .806 & 56.652 & 3.000 & 41.000 & .000 & .806 \\
\hline & Wilks' Lambda & .194 & 56.652 & 3.000 & 41.000 & .000 & .806 \\
\hline & Hotelling's Trace & 4.145 & 56.652 & 3.000 & 41.000 & .000 & .806 \\
\hline & Roy's Largest Root & 4.145 & 56.652 & 3.000 & 41.000 & .000 & .806 \\
\hline
\end{tabular}

Table 7

Levene's Test for Equality of Error Variances

\begin{tabular}{lllll}
\hline & F & df1 & df2 & Sig. \\
First Post-test & 1.594 & 3 & 43 & .205 \\
Second Post-test & .822 & 3 & 43 & .489 \\
\hline
\end{tabular}

Table 8

Tests of Between-Subjects Effects

\begin{tabular}{|c|c|c|c|c|c|c|c|}
\hline Source & $\begin{array}{l}\text { Dependent } \\
\text { Variable }\end{array}$ & Type III Sum of Squares & $\mathrm{df}$ & $\begin{array}{l}\text { Mean } \\
\text { Square }\end{array}$ & $\mathrm{F}$ & Sig. & Partial Eta Squared \\
\hline \multirow[t]{2}{*}{ Corrected Model } & First Post-test & $38.024^{\mathrm{a}}$ & 3 & 12.675 & 4.073 & .012 & .221 \\
\hline & Second Post-test & $51.394^{\mathrm{b}}$ & 3 & 17.131 & 5.646 & .002 & .283 \\
\hline \multirow[t]{2}{*}{ Intercept } & First Post-test & 7278.262 & 1 & 7278.262 & 2338.956 & .000 & .982 \\
\hline & Second Post-test & 6697.877 & 1 & 6697.877 & 2207.325 & .000 & .981 \\
\hline \multirow[t]{2}{*}{ Group } & First Post-test & 29.456 & 1 & 29.456 & 9.466 & .004 & .180 \\
\hline & Second Post-test & 39.324 & 1 & 39.324 & 12.960 & .001 & .232 \\
\hline \multirow[t]{2}{*}{ Error } & First Post-test & 133.806 & 43 & 3.112 & & & \\
\hline & Second Post-test & 130.479 & 43 & 3.034 & & & \\
\hline \multirow[t]{2}{*}{ Total } & First Post-test & 7755.000 & 47 & & & & \\
\hline & Second Post-test & 7192.000 & 47 & & & & \\
\hline \multirow[t]{2}{*}{ Corrected Total } & First Post-test & 171.830 & 46 & & & & \\
\hline & Second Post-test & 181.872 & 46 & & & & \\
\hline
\end{tabular}

Table 9

Pairwise Comparisons Between the Post-tests

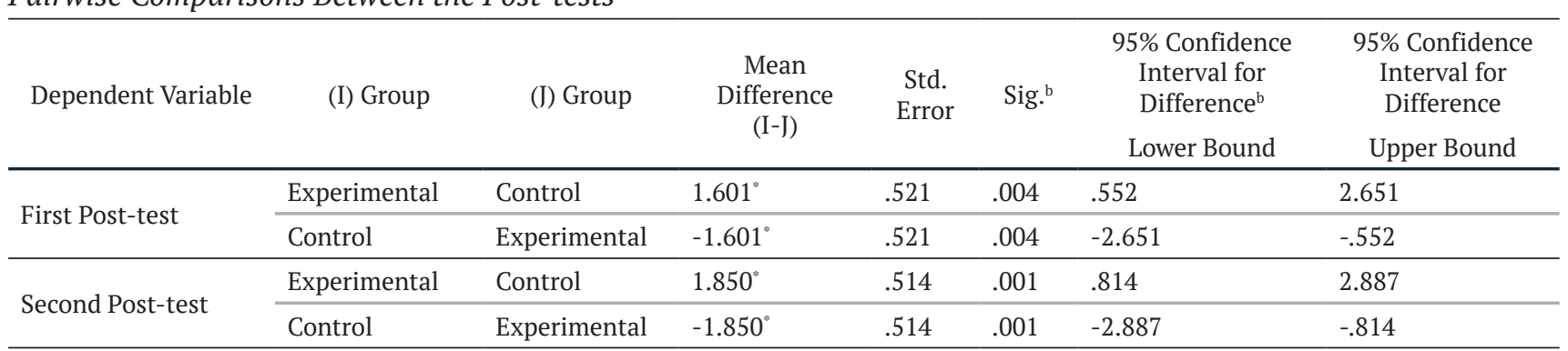

* The mean difference is significant at the .05 level.

b Adjustment for multiple comparisons: Bonferroni. 
paradigm of this study. Also, this study confirms the effectiveness of implicit instruction (Ellis, 2009), which provides learners with conditions to infer rules without awareness. Role play gives learners the opportunity to learn the rules while they are involved in language activities. The findings of the present study showed that the narrative writing of the participants was enhanced implicitly by engaging in the role-playing classes. They implicitly learned concepts like style, pattern, organization, characters, relationships, and imaginative thinking from the role-playing technique and used them in their narrative writing.

Moreover, the study showed the superiority of active learning over passive learning (Rogers, 2017). Role playing as the subset of active learning could encourage learners to participate more actively in the classroom tasks, either as observers or actors. The cognitive involvement of the students helped them to write what they had observed in the classroom. Likewise, the findings of the study can find support from flow theory (Csikszentmihalyi, 1990), as role playing was successful in producing the required conditions for learning.

The results of the present study could also be verified by Crumpler (2005), who asserted that drama engages young learners in thinking, doing, and imagining so that when they begin to compose texts they weave these threads together in unexpected and exciting ways. The findings of this study are also in line with Teitelbaum and Gillis (2004), who found a positive correlation between role playing and writing ability. Additionally, this study finds support from Moore and Caldwell (1993) who examined the value of drama work as a rehearsal for writing and looked at how drama promotes the narrative writing of the primary school children. However, this study contradicts Bitchener and Ferris (2012), who asserted that strategies relevant to reading and writing should be taught explicitly.

After three sessions, most of the participants eagerly volunteered to perform the roles. The reason could be that role playing reduces the fear of the learners to participate in the activities, which is in line with Golebiowska (1987).

After the treatment, participants took two Posttests; one was identical to the Pre-test and the second one was on an unseen topic. The reason for this design was to examine the difference between the participants' writing ability from the Pre to the Posttest. However, to control the effect of test-wiseness, the participants wrote on an unrehearsed topic, as well. The analysis of the results indicated that the difference between the experimental and control groups was larger in the second Post-test than the first Post-test. The primary reason could be that the topic of the second Post-test 'write a story about a scary dream you had' was narrower in scope than the topic for the first Post-test 'write a story about a memory that you will never forget' and it demanded more capability in the narrative writing on the side of the learners. The topic for the first Post-test was a broad topic and most of the participants wrote their stories based on a real memory (the researcher asked the students whether their stories were real or fictional). On the contrary, in the second Post-test, most of the participants wrote fictional stories because some of the participants asserted that they never remembered their dreams and some of them claimed that they had never experienced a scary one. As a result, the differences between the narrative writing of the two groups were more evident in the second Post-test, and those who engaged in the experimental groups performed better than the control groups. The second reason could be that the topic for the first Post-test was the same as the topic in the Pre-test and both groups in the experimental and control groups were familiar with it, and they did not try to improve their stories. Maybe they only tried to copy what they had remembered from the Pre-test because it was boring for them to write about the same topic. As a result, the differences between the narrative writing of the participants in the experimental and control groups were less evident in the first Post-test than the second one.

\section{Conclusion}

Writing is a complex task and EFL learners have to deal with too many variables, including coherence, cohesion, and organization, in addition to grammar and content, while engaged in a writing activity. Iranian EFL learners are confronted with a plethora of problems in writing in a second language because it is rarely utilized in real life conversations or situations (Raftari, Ismail, \& Eng, 2016). Narrative writing, as one of the four main types of writing (expository, descriptive, persuasive, and narrative), occurs when an individual recounts an event or experience from his/ her point of view (Carter, 1993). There are different ways to improve the narrative writing ability of EFL learners. The present study aimed to examine whether role playing in storytelling classes could affect Iranian young EFL learners' narrative writing ability. The analysis of the results signified that the use of role playing in the storytelling classes had a significant impact on the narrative writing of Iranian young EFL learners as compared to the reading a story aloud technique.

Furthermore, the findings signified that using role playing in storytelling classes enhanced learners' understanding of the narrative writing style and 
patterns of the target language. By using the roleplaying technique, all of the learners including the most silent and timid members participated in some way, either as observers or as actors. Using role playing in storytelling classes shortens the energy that is needed for teaching writing and reduces the negative impact of too many corrections. By using this technique, teachers can provide a learning atmosphere in which learners can actively participate in the process of instruction. Learning will take place in a joyful setting for both teachers and learners. We suggest researchers investigate the impact of role playing in storytelling classes on learners' interest and enthusiasm for writing. It would also be a good idea to study the effect of different genres of role playing on the narrative writing of EFL learners.

Finally, it is worth mentioning that when teachers want to use role playing in storytelling classes, they should select stories based on the applicability of assigning the characters of the stories to the learners who are participating in the role-playing activity.

\section{References}

Abbasi, S. (2017). The effect of using task-based activities on narrative writing performance of EFL learners with different personality types. Journal of Applied Linguistics and Language Research, 4(3), 2836.

Adam, A. (2015). Developing EFL learners' narrative writing through using short stories. European Journal of English Language and Literature Studies, $3(4), 1-8$.

Alabsi, T. (2016). The effectiveness of role play strategy in teaching vocabulary. Theory and Practice in Language Studies, 6(2), 227-234. doi:10.17507/ tpls.0602.02

Altun, M. (2015). Using role-play activities to develop speaking skills. Journal of Proceedings, 3(2), 354362.

Birjandi, P., \& Malmir, A. (2009). The effect of taskbased approach on the Iranian advanced EFL learners' narrative vs expository writing. Iranian Journal of Applied Language Studies, 1(2), 1-26.

Bitchener, J., \& Ferris, J. (2012). Written Corrective Feedback in Second Language Acquisition and Writing. New York, NY: Routledge. Retrieved from https://www.taylorfrancis.com/ books/9781136836091

Boardman, A. (2002). Writing to communicate. New York, NY: Longman.

Brown, H. D. (2001). Teaching by principles: An interactive approach to language pedagogy (2nd ed.). New York, NY: Pearson Education.
Canale, M. (1983). From communicative competence to communicative language pedagogy. In J. C. Richards \& R. W. Schmidt (Eds.), Language and Communication (pp. 2-27). London, UK: Longman.

Carter, C. (1993). The place of story in the study of teaching and teacher education. Educational Researcher, 22(1), 5-12.

Cohen, J. (1988). Statistical power analysis for the behavioral sciences (2nd ed.). Hillsdale, NJ: Lawrence Earlbaum.

Cook, M. (2000). Writing and role play: A case for inclusion. Reading, 34(2), 74-78.

Crumpler, T. (2005). The role of educational drama in the composing processes of young writers. Routledge, 10(3), 357-363.

Csikszentmihalyi, M. (1990). Flow: The psychology of optimal experience. New York, NY: Harper \& Row.

Ellis, R. (1994). A theory of instructed second language acquisition. In N. C. Ellis (Ed.), Implicit and explicit learning of languages (pp. 79-114). San Diego, CA: Academic Press.

Evans, J. L., Saffran, J. R., \& Robe-Torres, K. (2009). Statistical learning in children with specific language impairment. Journal of Speech, Language, and Hearing Research, 52, 321-335.

Fraser, M. (2015). Drawing as a pre-write strategy in narrative writing for elementary English language learners (Unpublished doctoral dissertation). Northcentral University, AZ, USA.

Harmer, J. (2004). How to teach writing. New York, NY: Longman.

Huang, I. (2008). Role play for ESL/EFL children in the English classroom. The Internet TESL Journal, XIV(2). Retrieved from http://itselj.org/Techniques/ Huang-Role play.html

Leung, J. H., \& Williams, J. N. (2011). The implicit learning of mappings between forms and contextually derived meanings. Studies in Second Language Acquisition, 33, 33-55.

Miller, J. S. (2010). Rubric-based instruction. In R. Bowers Sipe (Ed.), Strategies for writers (pp. 10-11). Grandview Heights, OH: Zaner-Bloser.

Moore, B., \& Caldwell, H. (1990). The art of planning; drama as rehearsal for writing in the primary grades. Youth Theatre Journal, 4(3), 13-20.

Moore, B., \& Caldwell, H. (1993). Drama and drawing for narrative writing in primary grades. Journal of Educational Research, 87(2), 100-110.

Ormrod, J. E. (2012). Human learning (6th ed.). Upper Saddle River, NJ: Pearson/Merrill Prentice Hall.

Raftari, S Smith., Ismail, S. A. M., \& Eng, L. S. (2016). Iranian EFL learners' writing problems: A move towards solution. Journal of Studies in Education, 6(4), 110-118.

Reber, A. S. (1967). Implicit learning of artificial grammars. Journal of Verbal Learning and Verbal 
Behavior, 6, 855-863.

Rogers, J. (2017). Awareness and learning under incidental learning conditions. Language Awareness, 26(2), 113-133.

Rogers, S., \& Evans, J. (2008). Inside role play in early childhood education: Researching young children's perspectives. Oxon, UK: Routledge.

Sadeghi, K., \& Sharifi, F. (2013). The effect of postteaching activity type on vocabulary learning of elementary EFL learners. English Language Teaching, 6(11), 65-76.

Smith, C. (2011). Narrative writing in native English and ESL learners: Development trajectories and predictors (Unpublished doctoral dissertation). University of Toronto, Toronto, Canada.

Teitelbaum, T., \& Gillis, S. F. (2004). Arts education: A review of the literature. Retrieved from http://www. esc.org/html/Document.aaaasp?chouseid $=6249$

Tompkins, K. P. (1998). Role playing/simulation. The Internet TESL Journal, 4(8). Retrieved from http:// iteslj.org/Techniques/Tompkins-Role playing.html Toumpaniari, K., Loyens, S., Mavilidi, M. F., \& Paas, F. (2015). Preschool children's foreign language vocabulary learning by embodying words through physical activity and gesturing. Educational Psychology Review, 1-12. Retrieved from http://ink. springer.com/article/10.1007/s10648-015-9316-4

Winter, B., \& Reber, A. S. (1994). Implicit learning and the acquisition of natural languages. In N. C. Ellis (Ed.), Implicit and explicit learning of languages (pp. 115-146). San Diego, CA: Academic Press. 
Appendix A

GADOE Eighth Grade Writing Rubric- Genre: Narrative

Points

Criteria

The student's response is a well-developed narrative that fully develops a real or imagined experience based on atext as a stimulus.

- $\quad$ Effectively establishes a situation, a point of view, and introduces a narrator and/or characters

- $\quad$ Organizes an event sequence that unfolds naturally

- $\quad$ Effectively uses narrative techniques, such as dialogue, description, pacing, and reflection to develop rich, interesting experiences, events, and/or characters

4 - Uses a variety of words and phrases consistently and effectively to convey the sequence, signal shifts from one time frame or setting to another, and show the relationships among experiences and events

- Uses precise words, phrases, and sensory language to convey experiences and events and capture the action

- $\quad$ Provides a conclusion that follows from the narrated experiences or events

- Integrates ideas and details from source material effectively

- Has very few or no errors in usage and/or conventions that interfere with meaning*

The student's response is a complete narrative that develops a real or imagined experience based on a text as a stimulus.

- $\quad$ Establishes a situation and introduces one or more characters

- $\quad$ Organizes events in a clear, logical order

- Uses narrative techniques, such as dialogue, description, pacing, and reflection to develop experiences, events, and/ or characters

- Uses words and/or phrases to indicate sequence, signal shifts from one time or setting to another, and show the relationships among experiences and events

- Uses words, phrases, and details to convey events

- $\quad$ Provides an appropriate conclusion

- Integrates some ideas and/or details from the source material

- Has little or no errors in usage and/or conventions that interfere with meaning*

The student's response is an incomplete or oversimplified narrative based on a text as a stimulus.

- Introduces a vague situation and at least one character

- $\quad$ Organizes events in a sequence but with some gaps or ambiguity

- Attempts to use a narrative technique, such as dialogue. description, pacing, or reflection to develop experiences, events, and/or characters

2 - Uses occasional signal words inconsistently and ineffectively to indicate sequence, signal shifts from one time or setting to another, and show the relationships among experiences and events

- Uses some words or phrases inconsistently and ineffectively to convey experiences and events and capture the action

- $\quad$ Provides a weak or ambiguous conclusion

- $\quad$ Attempts to integrate ideas or details from the source material

- Has frequent errors in usage and conventions that sometimes interfere with meaning*

The student's response provides evidence of an attempt to write a narrative based on a text as a stimulus.

- $\quad$ Provides a weak or minimal introduction of a situation or character

- Maybe too brief to demonstrate a complete sequence of events, or signal shifts in time or setting, or show relationships among experiences and events

1

- $\quad$ Shows little or no attempt to use dialogue or description

- Uses words that are inappropriate, overly simple, or unclear

- Provides few if any words that convey experiences or events and capture the action

- $\quad$ Provides a minimal or no conclusion

- $\quad$ May use few if any ideas or details from the source material (8.W.9)

- Has frequent major errors in usage and conventions that interfere with meaning*

- $\quad$ The response is completely irrelevant or incorrect, or there is no response.

- $\quad$ The student merely copies the text in the prompt.

- The student copies so much text from the passages that there is not sufficient original work to be scored.

* Students are responsible for language conventions learned in their current grade as well as in prior grades. Refer to the language skills for eachgrade to determine the grade-level expectations for grammar, syntax, capitalization, punctuation, and spelling. Also, refer to the Progressive Skillschart for those standards that need continued attention beyond the grade in which they were introduced. 
Appendix B

Name of the Stories

\begin{tabular}{lllll}
\hline & \multicolumn{1}{c}{ Name of the Story } & \multicolumn{1}{c}{ Author } & \multicolumn{1}{c}{ Publisher } & \multicolumn{1}{c}{ Website Address } \\
\hline 1 & Sara Says No! & NormanWhitney & Heinemann ELT & zabanAmoozan.com \\
\hline 2 & Alissa & C.J. Moore & Macmillan Readers & zabanAmoozan.com \\
\hline 3 & A Song for Ben & Sandra Slater & Oxford University Press & zabanAmoozan.com \\
\hline 4 & Paul and Pierre in Paris & H.Q. Mitchell & mmpublications & zabanAmoozan.com \\
\hline 5 & Six Sketches & Leslie Dunkling & Penguin Readers & penguinreaders.com \\
\hline 6 & Robin Hood & John Escott & Oxford University Press & zabanAmoozan.com \\
\hline 7 & Pirates of the Caribbean & Irene Trimble & Penguin Readers & penguinreaders.com \\
\hline
\end{tabular}

